\title{
РОЛЬ ТА ПРОБЛЕМИ ГУМАНІТАРНОЇ ПІДГОТОВКИ МАЙБУТНІХ ТЕХНІЧНИХ ФАХІВЦІВ АВІАЦІЙНОЇ ГАЛУЗІ
}

\section{М. В. Кірюхіна}

Кременчуцький національний університет імені Михайла Остроградського,

вул. Першотравнева, 20, м. Кременчук, 39614, Україна. E-mail: marinaarina1230@ gmail.com

Визначено роль гуманітарної підготовки майбутніх фахівців інженерно-технічних спеціальностей у закладах вищої освіти України та у їх складі технічних фахівців авіаційної галузі. Доведено, що гуманітарна підготовка разом із спеціальною професійною підготовкою забезпечує соціальну і професійну адаптацію, мобільність майбутнього фахівця на ринку праці, здатність до самоосвіти та самовдосконалення. Встановлено, що основні проблеми гуманітарної підготовки пов'язані із ізольованістю циклу навчальних дисциплін гуманітарної підготовки, відсутністю міждисциплінарної інтеграції; невідповідністю сучасними вимогам змісту, форм, методів та підходів до викладання навчальних дисциплін гуманітарного циклу; відсутністю кооперації випускових кафедр і кафедр гуманітарної підготовки; недоццінкою студентами значення гуманітарних знань та відсутністю мотивації до їх вивчення. Зроблено висновок, що гуманітарна підготовка повинна будуватись на основі інтеграції змісту гуманітарних, природничих та професійно зорієнтованих навчальних дисциплін, гуманітарні знання повинні бути професійно-спрямовані.

Ключові слова: гуманітарна підготовка, гуманітарні знання, технічні фахівці, авіаційна галузь.

\section{М. В. Кирюхина}

\section{РОЛЬ И ПРОБЛЕМЫ ГУМАНИТАРНОЙ ПОДГОТОВКИ БУДУЩИХ ТЕХНИЧЕСКИХ СПЕЦИАЛИСТОВ АВИАЦИОННОЙ ОТРАСЛИ}

Кременчугский национальный университет имени Михаила Остроградского

ул. Первомайская, 20. г. Кременчуг, 39614, Украина. E-mail: marinaarina1230@gmail.com

Определена роль гуманитарной подготовки будущих специалистов инженерно-технических специальностей в высших учебных заведениях Украины и в их составе технических специалистов авиационной отрасли. Доказано, что гуманитарная подготовка вместе со специальной профессиональной подготовкой обеспечивает социальную и профессиональную адаптацию, мобильность будущего специалиста на рынке труда, способность к самообразованию и самосовершенствованию. Установлено, что основные проблемы гуманитарной подготовки связаны с изолированностью цикла учебных дисциплин гуманитарной подготовки, отсутствием междисциплинарной интеграции; несоответствием современным требованиям содержания, форм, методов и подходов к преподаванию учебных дисциплин гуманитарного цикла; отсутствием кооперации выпускающих кафедр и кафедр гуманитарной подготовки; недооценкою студентами значения гуманитарных знаний и отсутствием мотивации к их изучению. Сделан вывод, что гуманитарная подготовка должна строиться на основе интеграции содержания гуманитарных, естественных и профессионально ориентированных учебных дисциплин, гуманитарные знания должны быть профессионально-направленные.

Ключевые слова: гуманитарная подготовка, гуманитарные знания, технические специалисты, авиационная отрасль.

АКТУАЛЬНІСТЬ РОБОТИ. Останні роки український та міжнародний ринок авіаційних перевезень динамічно розвивається. Авіаційна галузь України, отримавши позитивний імпульс для розвитку, має потребу в авіаційних фахівцях нової генерації фахівцях із високим рівнем професіоналізму, загальною й авіаційно-професійною культурою, соціально та професійно мобільних, здатних самостійно здобувати необхідні знання та підвищувати рівень свого професіоналізму.

В царині авіаційної галузі численною $є$ група фахівців, які здійснюють технічне обслуговування повітряних суден і всі види забезпечення польотів. Змістом їх роботи $є$ комплекс задач, пов'язаних із технічним обслуговуванням авіаційної техніки i ремонтом устаткування, а також заходів щодо поліпшення експлуатації повітряних суден, підвищенням ефективності і якості їх технічного обслуговування та ремонту, тому основний акцент під час професійної підготовки технічних кадрів авіаційної галузі у закладах вищої освіти робиться на професійно-орієнтованих навчальних дисциплінах, тоді як гуманітарній підготовці приділяється неналежна увага.
Домінування техноцентричного середовища 3 культом спеціальних професійно-орієнтованих навчальних дисциплін, у якому на перший план виступає підготовка «вузького» спеціаліста, підготовленого до ефективного виконання призначених йому функцій характерне не тільки в царині підготовки технічних фахівців авіаційної галузі, а і при підготовці інженерно-технічних фахівців інших галузей. Але, сьогодні, в умовах інформаційного і технологічного вибуху, спеціальна професійна підготовка старішає так само швидко, як техніка, технології, устаткування. Професійні знання та вміння це значна, але тільки частина, необхідна для побудови професійної кар'єри, інша частина - це особистісні та організаторські здібності фахівця, уміння спілкуватись, здатність до самоосвіти тощо. Саме гуманітарна підготовка забезпечує соціальну і професійну адаптацію, мобільність майбутнього фахівця, розвиває пам'ять, увагу, критичну спрямованість мислення, збільшує діапазон академічних та життєвих навичок необхідних для успішної професійної діяльності у міжкультурному просторі світового ринку.

Аналіз науково-педагогічної літератури показав, що роль, стан та проблеми гуманітарної підготовки майбутніх фахівців інженерно-технічних спеціаль- 
ностей у закладах вищої освіти у різних аспектах досліджували ряд науковців: Гуцоляк О., Лузік $\mathrm{C}$, Попенко Н., Шевчук Т. (роль гуманітарної підготовки в системі вищої технічної освіти); Васянович Г., Олійник О. (особливості гуманітарної підготовки і професійної компетентності студентів у технічному 3ВО); Вознюк О., Каверіна О. (формування системи гуманітарних інтегрованих знань студентів технічних університетів); Романова С., Таможська I., Товажнянський Л. (гуманітаризація професійної освіти у ЗВО технічного профілю); Бабушкіна В., Непомнящий А. (проблеми інтеграції гуманітарних і технічних дисциплін у ВТНЗ); Плачинда Т. (зарубіжний досвід гуманітарні підготовка фахівців авіаційної галузі); Барановська Л.В. та Барановський М.M. (формування особистість майбутнього фахівці авіаційної галузі) та ін.

Численні дослідження науковців доводять, що поєднання гуманітарної та професійно-орієнтованої підготовки майбутніх фахівців технічних спеціальностей одна 3 найактуальніших як проблем так i завдань діяльності закладів вищої освіти.

Метою статті $є$ вивчення думок науковців щодо ролі та проблем гуманітарної підготовки майбутніх фахівців з технічних спеціальностей.

МАТЕРІАЛ І РЕЗУЛЬТАТИ ДОСЛІДЖЕННЯ. Модернізація вищої освіти України, їі інтеграція у європейську та світову систему освіти вимагає переосмислення основних напрямів професійної підготовки фахівців, зокрема фахівців технічних спеціальностей.

Тенденцією сьогодення є гуманітаризації технічної освіти та технізації гуманітарної. У стратегічних законодавчих та освітніх документах країни, в Законі України «Про вищу освіту», Державній національній програмі «Освіта» (Україна XXI століття), Бухарестському комюніке (2012р.), Національній стратегії розвитку освіти України на період 20122021 рр. проголошено принципи гуманітаризації освіти.

У Державній національній програмі «Освіта» («Україна XXI століття») серед стратегічних завдань реформування змісту освіти визначено органічне поєднання у змісті освіти його загальноосвітньої та фахової складових, орієнтація на інтегральні курси, оптимальне поєднання гуманітарної і природничоматематичної складових освіти [1].

Актуалізація ролі гуманітарної підготовки фахівців технічних спеціальностей у закладах вищої світи підтверджується думками багатьох науковців. Як зазначає Віннікова Л., гуманізація освіти - це процес, спрямований не лише на розвиток нахилів $\mathrm{i}$ здібностей, які дозволяють людині подолати життєві труднощі, на створення умов для саморозвитку творчого потенціалу, а й на розуміння людини як найвищої ланки суспільства, ставлення до неї як до вищої цінності. Традиційна система освіти характеризується таким підходом до змісту освіти, при якому знання $є$ єдиною цінністю, відштовхуючи саму людину на друге місце [2 ].

На думку Негодаєва І., без гуманітарної складової фахівці технічних спеціальностей перетворюється на ремісників, які не знають нічого, крім вузькопрофесійних інтересів та приречені до життя у вакуумі. Науковець зазначає, що головне завдання гуманітарної підготовки полягає у передачі майбутнім фахівцям таких гуманітарних знань, які нині високо ціняться, є актуальні і затребувані, які роблять їх конкурентоспроможними, гнучкими, мобільними в сучасних економічних умовах [3]. Аналогічної думки дотримуються Король С. [4] та Шевчук Т. [5]. Сфера професійної діяльності інженера 3 вищою освітою не $є$ його ізольованими простором, а охоплює не тільки технічні й технологічні аспекти, а також організаторські, керівні, комунікативні, за які безпосередньо відповідає гуманітарна складова професійної підготовки. Відсутність таких знань і вмінь унеможливлює виконання своїх професійних обов'язків повною мірою, зменшує шанси кар'єрного зростання [4]. Окрім професійних знань i навичок, фахівці технічних спеціальностей повинні бути носієм високої загальної культури, яка формується гуманітарними, суспільнознавчими дисциплінами, які допомагають йому стати професіоналомтворцем, а не лише виконавцем [5].

Романовський О. стверджує, що тільки гуманітарна підготовка здатна дати людині можливість зрозуміти складність та багаторівневість буття, поглибити іï мислення, забезпечувати цілісність і системність світосприйняття, світорозуміння і світогляду [6].

Аналізуючи роль гуманітарної підготовки та іiі вплив на формування особистості майбутніх фахівців в системі вищої технічної освіти Гуцоляк О. зазначає, що дисципліни гуманітарного циклу, як філософія, соціологія, культурологія, політологія, історія, іноземна мова психологія, педагогіка тощо, що вивчаються у закладах вищої освіти, мають природний змістовий потенціал щодо формування всебічно розвиненої, високодуховної, гармонійної особистості, дають майбутнім фахівцям основні ціннісно-світоглядні орієнтації, вчать мислити і діяти конструктивно та творчо [7].

Таможська I. доводить, що якісне оволодіння професійними знаннями - необхідна, проте не достатня умова успішної життєдіяльності людини. В навчальному закладі студент має набути досвід соціальної взаємодії, оволодіти професійною майстерністю та творчою інтуїцією з урахуванням інтенсивно змінної картини природно-соціального сучасного світу, мати власне світобачення та громадянську позицію, виявляти високу компетентність у професійній діяльності [8].

Досліджуючи особливості гуманітарної підготовки і професійної компетентності студентів у технічному закладі вищої освіти Олійник О. зазначає, що мають допомогти людині: зрозуміти себе; з'ясувати психологічні механізми власної поведінки (психологія); визначити сутнісні характеристики суспільства, основні його елементи, закони і принципи взаємодії між ними, місце і роль людини в суспільстві, норми соціальної взаємодії (соціальна філософія, етика, право, соціологія); освоїти надбання світової і української культури (українознавство, світова та українська культура, культурологія, релігієзнавство); збагатитись світовим і вітчизняним соціальним досвідом, закономірностями історичного розвитку світового товариства і своєї батьківщини (всесвітня історія, історія України); навчитись цивілізованому спілкуванню з навколишнім середовищем, жити у злагоді з природою, оберігати і підтримувати ऑiі як умову спільного існування та розвитку (екологія, соціальна екологія); навчитись мислити, зрозуміти 
цілісність і багатомірність світу, сенс людського буття (філософію) [9].

Досліджуючи професійну підготовку фахівців авіаційної галузі, Барановська Л. [10] та Плачинда Т. [11] стверджують, що в професійному розвитку недооцінка ролі гуманітарних знань призводить до гальмування креативних потенцій мислення майбутніх фахівців, відсутності інтересу до духовної сфери майбутньої професії. Плачинда Т. зазначає, що гуманітарна освіта майбутніх авіаційних фахівців покращує їх когнітивні навички, розвиває пам'ять та увагу, збільшує діапазон академічних та життєвих навичок, що загалом сприяє їхній успішній життєдіяльності [11].

Акцентуючи увагу на необхідність гуманітарної підготовки майбутніх фахівців технічних спеціальностей, науковці акцентують увагу на проблеми пов'язані із ізольованістю, змістом, методами, формами та підходами до викладання навчальних дисциплін гуманітарного циклу у закладах вищої освіти.

Барановська Л. та Барановський М. [9], Вознюк О. [12], Костриця Н. [13], Олійник О. [9], Шевчук Т. [5] та інші науковці вказують на тенденцію вилучення із навчальних планів підготовки фахівців технічних спеціальностей дисциплін гуманітарного циклу та переведення їх в категорію вибіркових; ізольованість циклу навчальних дисциплін гуманітарної підготовки від навчальних дисциплін професійно спрямованого циклу; недостатню кількість аудиторних годин на вивчення гуманітарних дисциплін що призводить до фрагментарності гуманітарних знань; використання тестових методів перевірки знань студентів із гуманітарних предметів не дає змогу розуміння причинно-наслідкові зв'язки, логічність мислення, власної позиції.

Про невідповідність сучасними вимогам змісту навчальних дисциплін гуманітарної підготовки, необхідності оновлення їх змісту та впровадження міждисциплінарності у навчанні вказують Васянович Г. [14], Вознюк О. [12], Каверіна О. [15], Лузік Е. [16], Олійник О. [9], Романовський О. [6], Федорцова О. [17], Юрченко Н. [18] та ін.

Олійник О. та Юрченко Н. зазначають, що структура навчальних планів наповнена здебільшого теоретичним матеріалом 3 різних галузей гуманітарних знань, який за своєю концептуальною основою і змістом не відповідають вимогам сучасності; побудова навчального матеріалу гуманітарних дисциплін має переважно оглядово-інформаційний і репродуктивний характер [9; 18]. На дублювання, примітивізм, відсутність принципу інтегративності при розробці навчальних та робочих програм навчальних дисциплін гуманітарної підготовки вказує Васянович Г. [14].

На думку Романовського О., міждисциплінарність у навчанні в умовах дефіциту навчального часу сприяла би проникненню гуманітарного знання в природничо-наукові та технічні дисципліни, збагаченню гуманітарного знання природничонауковим i фундаментальним компонентами [6]. Аналогічної думки дотримується Григор'єва В. [19] та Каверіна О. [15].

Досліджуючи інтегративні тенденції розвитку змісту гуманітарної підготовки майбутніх інженерів, Каверіна О., вказує на слабкий взаємозв'язок загальноосвітніх, загальнотехнічних і спеціальних навчальних дисциплін, що є причиною відсутності інтег- ративності політехнічних знань [15]. Григор'єва В. та Шевчук Т. стверджують, що варто запроваджувати навчальні курси гуманітарних дисциплін з урахуванням спеціалізації та рівнів кваліфікації майбутніх інженерно-технічних фахівців; бажано обмежити навчальні програми з філософії, культурології, соціології, психології базовими поняттями та концептуальними ідеями; додати більш наближені до професійної підготовки студентів спецкурси на основі об'єднання спеціально відібраних «блоків» 3 галузей естетики, етики, філософії, психологічного практикуму з формування «почуття впевненості в собі» ін. $[19 ; 20]$.

На думку Козловської І. та Стечкевич О. існують певні труднощі у співвідношенні навчальних дисциплін, котрі забезпечують оволодіння професійними знаннями, та дисциплін, які формують духовний світ людини. Виникає проблема перевантаження студентів навчальним матеріалом, якщо намагатися ізольовано включати у навчальний план як профілюючі, так і гуманітарні предмети. Одним із можливих шляхів вирішення проблеми співвідношення базових та гуманітарних предметів у вузах технічного профілю $\epsilon$ : впровадження у навчальний процес інтеграції, а саме включення певних відомостей 3 фундаментальних та прикладних наук а канву гуманітарних предметів 3 метою формування у студентів цілісного уявлення про природу, людину та суспільство; розробка інтегрованих курсів гуманітарних предметів, які б забезпечували формування повноцінної особистості випускника технічного вузу, а разом $з$ тим, займали мінімум навчального часу [21].

Одним із провідних чинників відбору змісту підготовки спеціалістів, на думку Федорцової О. є синтезування професійних і гуманітарних знань та взаємозв'язок перспектив розвитку системи освіти, виробництва, техніки, праці, ринку кваліфікованих кадрів і культури [17].

Проаналізувавши зміст підручників і посібників 3 гуманітарних дисциплін, Лузік Е. стверджує, що навчальна література часто послуговується застарілим ідеологемам, віджилим стереотипам, позначається недоречностями, фактологічною суперечливістю, описовістю й декларативністю [16].

Барановська Л. та Барановський М. [10] зазначають, що підхід до змісту професійної підготовки майбутніх фахівців авіаційної галузі, заснований на обов'язковості лише когнітивного та діяльнісного компонентів i нехтуванні емоційно-ціннісним та творчим, формує в самих студентів стереотипні уявлення щодо моделі майбутнього спеціаліста, структури його професійної компетентності.

На проблеми пов'язаних із формами (часто застарілими) та методами викладання гуманітарних дисциплін вказують Олійник О. [9], Попенко Н. [22], Шевчук Т.[5; 20] та інші науковці.

Як зазначає Олійник О., сучасні методи викладання гуманітарних дисциплін частіше затемнюють зміст, ніж розкривають його, студенти запам'ятовують і відтворюють (переказують) інформацію, але не в змозі використати здобуті знання у новій ситуації, їхні знання скоріше визначаються шириною обсягу, ніж глибиною розуміння. ВНЗ повинен вчити студента мати власну думку, повинен стати школою мислення, а не школою запам'ятовування і відтворення інформації [9]. 
Шевчук Т. [5] вказує на необхідність впровадження проблемних методів викладання гуманітарних дисциплін, без яких неможливо сформувати у студентів навички самостійного аналізу актуальних проблем розвитку суспільства, навчити долати труднощі майбутнього самостійного життя. Науковець зазначає, що сьогодні в аудиторії має бути повний політичний, світоглядний суверенітет і плюралізм думок; активне, небоязливе висловлення студентами своєї позиції, власної думки, повний політичний, світоглядний суверенітет і плюралізм думок - це основа викладання гуманітарних дисциплін. На аудиторних заняттях студенти не повинні бути пасивними споживачами знань, а вміти аналізувати навчальний матеріал, самостійно робити висновки, застосовувати теоретичні знання в реальному житті.

У більшості сучасних ВТНЗ України викладання зводиться до заучування загально-теоретичних положень, до того ж, не завжди чітко сформульованих. Як результат - студенти зустрічаючись в житті 3 нестандартними ситуаціями, опиняються безпомічними щодо їхнього аналізу, виявлення причин і наслідків [20].

Серед причин неефективної гуманітарної підготовки науковці називають:

- відсутність кооперації профільних випускових кафедр і кафедр гуманітарної підготовки і як наслідок недостатні знання викладачів гуманітарних дисциплін особливостей професійної діяльності фахівців технічних спеціальностей 3 одного боку та технократичний стиль мислення у значної частини викладачів професійно-орієнтованих навчальних дисциплін, який вони передають студентам із перших днів навчання у ВН3;

- недооцінка студентами значення гуманітарних знань для їхньої успішної професійної діяльності і як наслідок відсутність мотивації до їх вивчення;

- невміння студентів організовувати і здійснювати діяльність із самостійного набуття гуманітарних знань;

- відсутність інтерактивних методів імітування майбутньої професійної діяльності фахівців у процесі гуманітарної підготовки;

- відсутність визначення ролі кожної гуманітарної дисципліни в майбутній професійній діяльності фахівця [12; 15; 19].

ВИСНОВКИ. Узагальнивши думки науковців можна констатувати, що гуманітарна підготовка повинна бути обов'язковою та рівноправною складовою професійної підготовки майбутніх фахівців технічних спеціальностей, в тому числі майбутніх технічних фахівців авіаційної галузі. Але, це повинні бути професійно-спрямовані гуманітарні знання, якими оперуватиме майбутній фахівець у сфері своєї професійної діяльності.

До подальших розвідок у цьому напрямі відносимо вивчення особливостей гуманітарної підготовки технічних фахівців авіаційної галузі у розвинених країнах світу, вдосконалення змісту гуманітарної підготовки в закладах вищої технічної освіти на основі інтеграції змісту гуманітарних, природничих та професійно зорієнтованих навчальних дисциплін. Окреслена проблема $є$ перспективною та потребує подальшого дослідження.

\section{ЛІТЕРАТУРА}

1. Семенець-Орлова I. А. Нормативно-правове забезпечення освітніх змін в Україні. Теорія ma практика державного управління. 2017. № 3(58). C. $1-10$.

2. Віннікова Л. Ф. Деякі напрямки гуманізації фахової підготовки студентів вищих навчальних закладів. Наукові записки НДУ ім. М. Гоголя. Серія: Психолого-педагогічні науки. 2014. № 5. С. 130-132.

3. Негодаев И. Гуманитарное знание как органическая часть знания инженера. Проблемы развития и интеграции науки, профессионального образования и права в третьем тысячелетии : материалы научной конференции с международным участием, Красноярск, 23-25 окт. 2001 г. Красноярск, 2001. C. 496.

4. Король С. В. Роль гуманітарних знань у підготовці фахівців інженерного профілю. URL: http://www.rusnauka.com/28_OINXXI_2010/Pedagogic a/72646.doc.htm (дата звернення: 10.03.2019).

5. Шевчук Т. Є. Роль гуманітарної підготовки в технічному ВНЗ. Науковий вісник Миколаївського національного університету ім. В. О. Сухомлинського. Педагогічні науки. Миколаїв, 2016. №1 (52). C. $70-76$

6. Романовский А. Г. Психолого-педагогическая подготовка в свете концепции формирования гуманитарно-технической элиты. Харьковская школа психологии: наследие и современная наука. 2012. C. 129-139.

7. Гуцоляк О. О. Роль гуманітарної підготовки як складової формування особистості майбутніх фахівців в системі вищої технічної освіти. Проблеми та перспективи формування національної гуманітарно-технічної еліти. Харків: НТУ «ХПІ», 2012. № 32-33. C. 46-55.

8. Таможська I. В. Теоретичні питання формування вмінь ділового спілкування в майбутніх фахівців технічного профілю. Science and Education a New Dimension: Pedagogy and Psychology. Budapest, 2013. Vol. 7. C. 173-176.

9. Олійник О. Особливості гуманітарної підготовки і професійної компетентності студентів у технічному BH3. URL: http://litmisto.org.ua/?p=19946 (дата звернення: 05.03.2019).

10. Барановська Л. В., Барановський М. М. Проблеми формування духовної культури майбутніх фахівців технічної галузі. Наукові записки Начіонального університету «Острозька академія». Серія: Психологія і педагогіка. 2012. №. 21. С. 186-190.

11. Плачинда Т. Професійна підготовка фахівців авіаційної галузі: зарубіжний досвід. Науковий вісник Льотної академії. Серія : Педагогічні науки. 2017. № 2. C. 152-160.

12. Вознюк О. М. Особливості вивчення гуманітарних дисциплін у технічних університетах. Bicник НТУУ «КПІ». Серія «Філософія. Педагогіка». 2006. № 1. C. 96-98.

13. Костриця Н. М. Гуманізація аграрної освіти в контексті освітніх змін. Вісник Львівського універcumemy. Серія педагогіка. 2009. № 25. С. 256-262.

14. Васянович Г. П. Гуманітарна освіта у процесі підготовки технічної еліти України. Проблеми та перспективи формування національної гуманітарно-технічної еліти: зб. наук. праць НТУ «ХПІ». Харків: НТУ «ХПІ», 2010. № 27 (31). С. 97-102. 
15. Каверіна О. Г. Інтегративні тенденції розвитку змісту гуманітарної підготовки майбутніх інженері. Інформаційні технології і засоби навчання: електрон. наук. фахове вид. 2009. №6 (14). URL: http://www.ime.edu-ua.net/em.html.

16. Лузік Е. В. Гуманітарна освіта в процесі підготовки спеціалістів профільних ВНЗ України : проблеми та перспективи. Філософія освіти. 2006. № 2(4). С. 266-276.

17. Федорцова О. Г. Проблемні аспекти навчання і виховання майбутнього інженера засобами вивчення гуманітарних дисциплін. Вісник Житомирського державного університету ім. I. Франка. Житомир, 2012. № 63. С. 173-176.

18. Юрченко Н. С. Сучасний стан гуманітарної підготовки майбутніх інженерів-педагогів. Науковий часопис НПУ імені М. П. Драгоманова. Серія 13: Проблеми трудової та професійної підготовки. Київ, 2017. № 9. C. 111-115.
19. Григор'єва В. А. Шляхи вдосконалення гуманітарної підготовки майбутніх інженерів. Збірник наукових праць Херсонського державного університету. Педагогічні науки. 2018. № 82(3). С. 126-129.

20. Шевчук Т. С. Особливості гуманітарної підготовки в технічному ВНЗ: проблеми і перспективи. Science and Education a New Dimension: Pedagogy and Psychology. Budapest, 2019. № IV(39). C. 74-79.

21. Козловська I. М., Стечкевич О. О. Інтеграція змісту природничо-гуманітарного компоненту у підготовці майбутніх фахівців технічного профілю. Молодий вчений. 2018. № 8 (60). С. 150-153.

22. Попенко Н. В. Роль соціально-гуманітарних дисциплін у професійній підготовці фахівців природничих спеціальностей. Наукові записки кафедри педагогіки Сумського державного університету. 2017. № 41. C.180-190.

\section{ROLE AND PROBLEMS OF HUMANITARIAN TRAINING FOR FUTURE TECHNICAL SPECIALISTS IN AVIATION INDUSTRY}

\section{Kiriukhina}

Kremenchuk Mikhailo Ostrogradskyi National University

vul. Pershotravneva 20, Kremenchuk, 39600, Ukraine. E-mail: marinaarina1230@gmail.com

Purpose. The article aims to study the opinions of scientists about role and problems of humanitarian training of future specialists in technical majors. Methodology. The research uses theoretical methods, among which are the following: theoretical and systematic analysis of scientific and educational literature, systematization, generalization of information. Results. The role of humanitarian training of future specialists in engineering and technical specialties in institutions of higher education of Ukraine and their technical specialists in the aviation industry is determined. It is proved that the humanitarian training of future technical specialists in aviation industry, along with special professional training, ensures social and professional adaptation, mobility of future specialist in the labor market, ability to self-education and self-improvement. It is established that the main problems of humanitarian training are connected with the isolation of the humanitarian educational disciplines training cycle, the lack of interdisciplinary integration; inconsistency with modern requirements of content, forms, methods and approaches to teaching of humanitarian disciplines; lack of cooperation between graduate departments and departments of humanitarian training; the students underestimation of the importance of humanitarian knowledge and lack of motivation to study them. Originality. It was proved the necessity of further development of the idea of improving the training of future specialists in the context of humanization of higher technical education. Practical value. The main reasons of ineffective humanitarian training of specialists of technical specialties in institutions of higher education are established. Conclusions. Humanitarian training of future technical specialists in aviation industry should be based on integration of content of humanities, natural sciences and professionally oriented academic disciplines. The humanities should be professional-oriented, which will be operated by a future specialist in the field of professional activities.

Key words: humanitarian training, humanitarian knowledge, technical specialists, aviation industry.

\section{REFERENCES}

1. Cemenecz-Orlova, I. A. (2017), "Normatyvnopravove zabezpechennya osvitnix zmin $\mathrm{v}$ Ukrayini [Regulatory support of educational changes in Ukraine]", Teoriya ta praktyka derzhavnogo upravlinnya, 3(58), 1-10.

2. Vinnikova, L. F. (2014), "Deyaki napryamky gumanizaciyi faxovoyi pidgotovky studentiv vyshhyx navchalnyx zakladiv [Some areas of humanization of professional training of students of higher educational institutions]", Naukovi zapysky NDU im. M. Gogolya. Seriya: Psyxologo-pedagogichni nauky, 5, 130-132.

3. Nehodaev, Y. (2001), "Humanytarnoe znanye kak orhanycheskaia chast znanyia ynzhenera [Humanitarian knowledge as an organic part of the knowledge of an engineer]", Problemy razvitiya i integracii nauki, professionalnogo obrazovaniya $i$ prava $v$ tret'em tysyacheletii: materialy nauchnoj konferencii $s$ mezhdunarodnym uchastiem, p. 496.

4. Korol, S. V. "Rol humanitarnykh znan u pidhotovtsi fakhivtsiv inzhenernoho profiliu [The role of humanitarian knowledge in the training of engineers]" URL: http://www.rusnauka.com/28_OINXXI_2010/Pedagogic a/72646.doc.htm

5. Shevchuk, T. E. (2016), "Rol humanitarnoi pidhotovky $\mathrm{v}$ tekhnichnomu VNZ [The role of humanitarian training at the technical universities]", Naukovyi visnyk Mykolaivskoho natsionalnoho universytetu im. V.O. Sukhomlynskoho. Pedahohichni nauky, 2(52), 7076.

6. Romanovskyi, A. H. (2012), "Psykholohopedahohycheskaia podhotovka $\mathrm{v}$ svete kontseptsyy formyrovanyia humanytarno-tekhnycheskoi eliti [Psychological and pedagogical training in the light of the concept of forming the humanitarian and technical elite]", Kharkovskaia shkola psykholohyy: nasledye y sovremennaia nauka, pp.129-139.

7. Hutsoliak, O. O (2012), "Rol humanitarnoi pidhotovky yak skladovoi formuvannia osobystosti maibutnikh fakhivtsiv v systemi vyshchoi tekhnichnoi osvity [Humanitarian role of training as a component of 
the formation of future experts in the higher technical education]", Problemy ta perspektyvy formuvannia natsionalnoi humanitarno-tekhnichnoi elity, vol. 32-33, pp. 46-55.

8. Tamozhska, I. V. (2013), "Teoretichni pitannya formuvannya vmin dilovogo spilkuvannya $\mathrm{v}$ majbutnih fahivciv tekhnichnogo profilyu [Theoretical approaches to the development of professional communicative competence of future specialists of technical profile]", Science and Education a New Dimension : Pedagogy and Psychology: journal, Vol. 7, pp.173-176.

9. Oliinyk, O. "Osoblyvosti humanitarnoi pidhotovky i profesiinoi kompetentnosti studentiv $u$ tekhnichnomu VNZ [Features of humanitarian training and professional competence of students in technical universities]", URL: http://litmisto.org.ua/?p=19946

10. Baranovska, L. V., Baranovskyi, M. M. (2012), "Problemy formuvannia dukhovnoi kultury maibutnikh fakhivtsiv tekhnichnoi haluzi [The Problems of Forming theSpiritual Culture of Future Specialists in theTechnical Industry]", Naukovi zapysky. Seriia "Psykholohiia i pedahohiia», 21,186-190.

11. Plachynda, T. (2017), "Profesijna pidgotovka fahivciv aviacijnoï galuzi: zarubizhnij dosvid [Professional training of specialists in the aviation industry: foreign experience]", Naukovij visnik L'otnoï akademiï. Seriya : Pedagogichni nauki, 2, 152-160.

12. Vozniuk, O. M. (2006), “Osoblyvosti vyvchennia humanitarnykh dystsyplin u tekhnichnykh universytetakh [Features of studying humanitarian disciplines in technical universities]", Visnyk NTUU «KPI». Filosofiia. Psykholohiia. Pedahohika, Vol.1, pp. 96-98.

13. Kostrytsia, N. M. (2009), "Humanizatsiia ahrarnoi osvity $\mathrm{V}$ konteksti osvitnikh zmin [Humanitarization of agricultural education in the context of educational change]", Visnyk Lviv. un-tu Ser. ped., Vol. 25, pp. 256-262.

14. Vasianovych, H. P. (2010), "Humanitarna osvita u protsesi pidhotovky tekhnichnoi elity Ukrainy [Humanitarian education in the process of technical elite training in Ukraine]", Problemy ta perspektyvy formuvannia natsionalnoi humanitarno-tekhnichnoi elity, Vol. 27 (31), pp. 97-102.

15. Kaverina, O. H. (2009), "Intehratyvni tendentsii rozvytku zmistu humanitarnoi pidhotovky maibutnikh inzheneriv [Integrative tendencies of the liberal training content development of the future engineers]", Informacijni tehnologiyi i zasobi navchannya, Vol. 5(14), URL: http://www.ime.edu-ua.net/em.html

16. Luzik, E. V. (2006), "Humanitarna osvita v protsesi pidhotovky spetsialistiv profilnykh VNZ Ukrainy : problemy ta perspektyvy [Humanitarian education in specialized training in higher education institutions of Ukraine: problems and prospects]", Filosofiia osvity, Vol. 2(4), pp. 266-276.

17. Fedortsova, O. H. (2012), "Problemni aspekty navchannia i vykhovannia maibutnoho inzhenera zasobamy vyvchennia humanitarnykh dystsyplin [The problem aspects of studies and education of the prospective engineer by means of studying the humanities]", Visnyk Zhytomyrskoho derzhavnoho universytetu im. I. Franka, Vol. 63, pp. 173-176.

18. Yurchenko, N. S. (2017), "Suchasnyi stan humanitarnoi pidhotovky maibutnikh inzhenerivpedahohiv [ The current state of humanitarian training of future engineering teachers]", Naukovyi chasopys NPU imeni M.P. Drahomanova. Seriia 13 : Problemy trudovoi ta profesiinoi pidhotovky, Vol. 9, pp. 111-115.

19. Hryhorieva, V. A. (2018), "Shliakhy vdoskonalennia humanitarnoi pidhotovky maibutnikh inzheneriv [Ways to improve humavitarian traivavg of future engineers]", Zbirnyk naukovykh prats Khersonskoho derzhavnoho universytetu. Pedahohichni nauky, Vol. 82(3), pp.126-129.

20. Shevchuk, T. E. (2016), "Osoblyvosti humanitarnoi pidhotovky $\mathrm{v}$ tekhnichnomu VNZ: problemy $\mathrm{i}$ perspektyvy [The peculiarities of the humanitarian training in technical Universities: problems and prospects]", Science and Education a New Dimension: Pedagogy and Psychology: journal, Vol. IV(39), pp. 74-79.

21. Kozlovska, I. M., Stechkevych, O. O. (2018), "Intehratsiia zmistu pryrodnycho-humanitarnoho komponentu u pidhotovtsi maibutnikh fakhivtsiv tekhnichnoho profiliu [Integration content of naturalhumanitary component in preparation of future specialists of the technical profile]", Molodyi vchenyi, Vol. 8 (60), pp. 150-153.

22. Popenko, N. V. (2017), "Rol sotsialnohumanitarnykh dystsyplin u profesiinii pidhotovtsi fakhivtsiv pryrodnychykh spetsialnostei [The role of social and humanities disciplines professional training of natural science specialists]", Naukovi zapysky kafedry pedahohiky, Vol. 41, pp. 180-190. 